\title{
Romanen som sproglig aktivisme
}

\section{Om Michel Butors Seks millioner otte hundrede ti tusind liter vand i sekundet}

\section{Nouveau Roman}

Michel Butor (f. 1926) hører til de forfattere, der i midten af 1950'erne bliver grupperet under samlebegrebet le nouveau roman, som vækker betydelig opsigt og kontrovers i samtiden. De markerer et eksperimenterende opbrud fra den traditionelle roman. Eller måske snarere: et genopbrud, eftersom der jo i det 20. århundredes første to tiår allerede har været en bølge af eksperimenterende opbrud i romanen på begge sider af første verdenskrig. - Le nouveau roman er en del af en bølge af fornyelsestrang i tiden, som også melder sig i billedkunsten og på f.eks. filmsiden, hvor vi kender den som nouvelle vague (med navne som Godard, Chabrol og Resnais. Den sidste samarbejdede bl.a med nouveau roman forfatteren Robbe-Grillet om den stærkt eksperimenterende film I fjor i Marienbad fra 1961). En bølge, som indleder det, man senere på internationalt niveau ofte har talt om som tresseravantgarden (ca. 1955-1968).

Le nouveau roman omfatter foruden Michel Butor, Alain Robbe-Grillet, Nathalie Sarraute, Claude Ollier, Claude Simon, Robert Pinget og Jean Ricardou (som både er forfatter og (især) kritiker), ligesom også Samuel Beckett og Marguerite Duras er blevet regnet med til gruppen.

Det er en meget heterogen gruppe. Sarrautes mest eksperimenterende værk Tropismes udkommer eksempelvis allerede i 1939, hvor den ikke vækker stor opmærksomhed, men genudkommer på forlaget Minuit i 1957, på et tidspunkt hvor den eksperimenterende bølge har skabt bedre gehør. ${ }^{1} \mathrm{Og}$ det er omstridt, om der overhovedet er tale om en egentlig gruppe med fællestræk, eller om det er ganske individuelle forfatterskaber og skrivemåder, der blot er blevet lanceret som en bevægelse af pressen. I modsætning til

1. Dansk oversættelse: Tropismer, Kbh. 1959. 
f.eks. surrealismen har le nouveau roman heller ingen tydelig anfører, intet fælles manifest og heller intet tidsskrift. Nouveau roman-gruppen er også kun én af flere eksperimenterende grupperinger i samtiden - en anden er den senere så kendte Tel Quel-gruppe omkring tidsskriftet af samme navn, der rummer en række forfattere og teoretikere som Philippe Sollers, Roland Barthes, Julia Kristeva m.fl.

Men der er dog fællestræk, som taler for samlebetegnelsen nouveau roman. Fællestrækkene rækker fra de helt udvendige - såsom at disse forfattere alle udkommer i midt-halvtredserne på Éditions de Minuit, hvad der signalerer smal litteratur, avantgarde - til de mere erklærede: De syv forfattere Sarraute, Robbe-Grillet, Butor, Ollier, Simon, Pinget, Ricardou træder frem som selvvalgt gruppering ved et seminar om »Nouveau Roman, hier, aujourd'hui« i Cerisy-la Salle organiseret af Ricardou i 1971, og markerer dermed, at de påtager sig navnet, mens Beckett og Duras holder sig borte. $\mathrm{Og}$ på trods af alle forskelle kan man udpege en række fællestræk ved deres romaner, der placerer dem som nouveau roman:

De er alle imod »l'illusion représentative«, den litteraturhistoriske skrivemåde, vi har vænnet os til at kalde 'realisme'. De ønsker ikke at reprcesentere eller reproducere en virkelighed, men at producere former, der kan ses som virkelighedsmodeller: muligheder for ny ind sigt i eller udblik til verden

De vil ikke sammenblande det litterære projekt og det menneskelige eller politiske engagement (efter Sartres model, som tegner fransk efterkrigslitteratur). Litteratur skal efter deres opfattelse ikke tjene som middel til politisk agitation (i realistisk forstand - men jeg skal vende tilbage til i hvilken anden forstand, disse romaner kan siges at have en eksistentiel og politisk dimension). Men flere af nouveau roman-forfatterne og også forlaget Minuit er politisk aktive og tager f.eks. offentlig stilling $\mathrm{i}$ forhold til datidens mest brændende spørgsmål i fransk politik: Algierkrigen og Frankrigs forhold til sine kolonier. I modsætning til efterkrigstidens såkaldt 'engagerede litteratur' mener nouveau roman-forfatterne, at litteratur er litteratur - mens politik er noget, som enhver må forholde sig til som borger og ansvarligt enkeltindivid.

Nouveau roman-forfatterne skriver alle, hvad man kan betegne som sprogromaner, hvad der bl.a. indebærer, at personerne ikke er udbygget i traditionel forstand, men kan reduceres til stemmer, til forbogstaver eller evt. blot til en synsvinkel eller synsmåde, en kameralinse; at handlingen ikke nødvendigvis følger en lineær spændingskurve, men evt. spaltes op i flere, måske usammenhængende versioner. Der kan være tale om montage af forskelligt materiale eller noget, der ligner filmklip (ikke mindst hos RobbeGrillet), analyser eller beskrivelser af mikroskopiske fimrebevægelser 
mellem personer i sociale situationer (Sarrautes tropismer) eller flere samtidige spor - som i den Butor-roman, der her er på tale.

I disse romaner er det deskriptive niveau fremtrædende. Der er ofte tale om en mere minutiøs beskrivelse af tingsverdenen end vanligt - og i modsætning til den foregående romantradition er deskriptionen her ikke underordnet narrationen. Tværtimod taler f.eks. Robbe-Grillet i de programmatiske og polemiske artikler, der er samlet i bogen Pour un nouveau roman ${ }^{2}$ imod romantraditionens 'antropomorfisme', dens tendens til at lade beskrivelser af omverden og tingsverden danne karakteriserende og psykologiserende baggrund for personskildringen (sådan som man f.eks. kender det fra Balzac, hvis beskrivelser ellers også kan være ganske omfangsrige), ligesom han vender sig imod de traditionelle kunstner- og kunstmyter om 'dybde' (forfatterens 'dybe' indsigt, som netop fremgår af romanens sammenfattende beskrivelser og er mere omfattende end romanpersonernes begrænsede perspektiv): I nouveau roman skal der ikke være nogen sådan forloren dybsindighed, men tværtimod åbnes mod læserens mere direkte perception af omverdenen, uden fortolkende filter. Butor taler i sine Essais sur le roman ${ }^{3}$ om planer, figurer, overflader, det optiske(s illusioner), dvs. formel konstruktion. Mens Nathalie Sarraute i l'Ère de soupçon taler mere kulturhistorisk og psykologisk om en 'mistankens æra', hvor forfatteren må søge ned under de færdigformulerede overflader til de minutiøse gestus og fornemmelser, der går forud for bevidsthedens og talens konventioner. Til fælles har disse forfattere således også et intellektuelt og kritisk præg, som tillader dem ikke blot at skrive yderst reflekteret fiktion, men også at gebærde sig på et teoretisk, i flere tilfælde også akademisk, niveau. Jean Ricardou har således forfattet flere analytiske og teoretiske værker om nouveau roman som Problèmes du nouveau roman og Pour une théorie du nouveau roman..$^{5}$

\section{Michel Butor}

Butor regnes (sammen med Robbe-Grillet) for en af romanformens fornyere i det 20. årh.s Frankrig. Han eksperimenterer især med at bryde romanens linearitet og skabe nye tids- og rum-opfattelser. Ofte må læseren selv samle

2. Paris 963. Dansk oversættelse: På vej mod en ny roman, Fredensborg 1965.

3. Paris 1975.

4. Paris 1956, ny udg. 1966.

5. Jean Ricardou; Problèmes du nouveau roman, Paris 1969, og Pour une théorie du nouveau roman, Paris 1971. 
brikkerne: identificere tid, sted/rum og personer som i en detektivisk undersøgelse. Det er åbne tekster, der fremlægger deres egne konstruktionsprincipper, som læseren så må medvirke til at realisere.

Butor har skrevet en lang række romaner, hvoraf flere hurtigt blev oversat til dansk. Debutbogen Passage de Milan udkommer i 1954, og derefter følger i hurtig rækkefølge flere andre romaner, som er med til at tegne nouveau roman: l'Emploi du temps (1956) ${ }^{6}$ som modtog Prix Fénéon; La modification (1957), ${ }^{7}$ som fik Prix Renaudot, er skrevet i 2. person (vous) og beskriver en togrejse, hvorunder 2 steder, Rom og Paris, stadig superimposeres; Degrès (1960) (en times historie- og geografiundervisning i en skole). Efter disse fire første romaner folder forfatterskabet sig ud i mange retninger og genrer. Michel Butor er både universitetslærer, litteraturkritiker (han har skrevet om bl.a. Montaigne, Jules Verne, Proust, Roussel, Leiris, Joyce, Pound, Faulkner m.fl.), forfatter til artikler om musik, kunsthistoriske emner (samlet i bl.a. Répertoires-serien (1960-82), i Illustrations (1964-76) og i Les mots sur la peinture (1969)), og til topografiske artikler (samlet i Génie du lieu-serien), foruden fire bind om drømmenes sprog. Han har lavet opera og radio og udgivet digte.

Butor har selv erklæret, at hans romaner ikke skal være lukkede enheder, men et rum for udforskning (jf. essayet "Le roman comme recherche» (1955) - som vi vender tilbage til), og midlerne i denne åbne udforskning er bl.a.:

- anvendelse af forskellig typografi (i bl.a. 6.810.000 litres d'eau par seconde (1965), ${ }^{8}$ og Réseau Aérien (1962) - som ikke blot er "stereofonisk prosa «, men papirudgaver af faktiske radioeksperimenter)

- brug af flere farver i teksten (Boomerang, 1980)

- stadig brug af deturnerede citater (som Chateaubriand-citatet i 6.810.000 litres d'eau)

- brug af collage og ready mades (i bl.a. Mobile, ètude pour une représentation des États-Unis, 1962 og Boomerang)

- sammenklipning af forskellige diskurser (iVanité, 1980)

- seriel gentagelse af tekstenheder, multiplikation af tekstversioner (i operaen Votre Faust)

- flere spor efter læsers valg (i Réseau aérien, Mobile og 6.810.000 litres d'eau)

- aritmetriske eller alfabetiske kombinatorikker (i Illustrations II, III og IV (1969 75), Matières de rêves (1975))

6. Dansk oversættelse: Tidens labyrint, Fredensborg 1964.

7. Dansk oversættelse: Valget, Fredensborg 1960.

8. Dansk oversættelse: 6.810.000 liter vand $i$ sekundet, Fredensborg 1967. 


\section{6.810.000 litres d'eau par seconde (1965)}

Bogen har mange af disse formeksperimenterende træk: den er delt op i 12 dele, svarende til et års forløb fra april til og med marts - hvad der angives først i hver del med et tekstbånd øverst på siden (APRIL APRIL APRIL APRIL APRIL APRIL/ NOVEMBER NOVEMBER NOVEMBER NOVEMBER) og også fremgår af indholdet. Inden for de enkelte dele er der ligeledes et kronologisk forløb, som udmåler tidens gang time for time ved klokkeslag fra Westminsters klokkespil (London), der tilsyneladende udgår fra klokketårnet i parken ved Niagara Falls, hvor bogen udspiller sig. Tidens gang markeres også i teksten, f.eks. ved at fortælleren siger, »det er aften «" og gennem beskrivelser af stedets udseende på forskellige årstider og tidspunkter. II del: MAJ begynder med et »lille forspil før klokken slår ni« om morgenen, og herfra tælles der fremad gennem de følgende dele, således at vi tre gange passerer midnat og slutter kl. 13 i sidste del: CODA. Ialt lidt over tre døgn, der ganske vist ligger konsekutivt i forlængelse af hinanden, men ifølge kapiteloverskrifterne altså fordelt hen over 11 måneder. Et ganske stramt system af dobbelt tidsregning, som strukturerer teksten. Romanen præges således af konstruktion - og orden i næsten klassisk form: tidens og stedets enhed.

De 12 dele har derudover hver sin titel:

$\begin{array}{llll}\text { I } & \text { Præsentation } & \text { April } & \text { (p. 7-14) } \\ \text { II } & \text { Parrene } & \text { Maj } & \text { (p. 15-36) } \\ \text { III } & \text { Negrene } & \text { Juni } & \text { (p. 37-58) } \\ \text { IV } & \text { Brudesløret } & \text { Juli } & \text { (p. 59-81) } \\ \text { V } & \text { Illumination } & \text { August } & \text { (p. 83-106) } \\ \text { VI } & \text { Værelserne } & \text { September } & \text { (p. 107-132) } \\ \text { VII } & \text { Opvågnen } & \text { Oktober } & \text { (p. 108-158) } \\ \text { VIII } & \text { Tågerne } & \text { November } & \text { (p. 159-182) } \\ \text { IX } & \text { Skyggerne } & \text { December } & \text { (p. 183-199) } \\ \text { X } & \text { Styx } & \text { Januar } & \text { (p. 201-224) } \\ \text { XI } & \text { Kulden } & \text { Februar } & \text { (p. 225-246) } \\ \text { XII } & \text { Coda } & \text { Marts } & (\text { p. 247-261) }\end{array}$

Hver del er tilrettelagt som et antal spor, hvad der indledningsvis forklares i »Præsentation« (p. $8+9$ ), som angiver, at »Travle læsere« kan vælge »det korte spor«, »Mindre travle læsere«»det lange spor«, men det anbefales også

9. Jeg henviser af forståelseshensyn til den danske udgave Seks millioner otte hundrede ti tusind liter vand $i$ sekundet, Fredensborg 1967, oversat af Anni Wieth-Knudsen, p. 90. De efterfølgende sidetal henviser til denne udgave. 
at udforske »alle otte mellemspor« og derved »opdage, hvorledes skiftende belysninger kan fremhæve nye former og aspekter i dette flydende monument $\ll$.

Den korte Præsentationsdel har kun et spor, hvor »speakeren« og »oplæseren« (der hele vejen befinder sig i »centrum«) taler vekselvis, mens de efterfølgende elleve dele alle har ti forskellige spor (mærket fra A til J) og et større galleri af personer fordelt til højre og venstre for speakeren og oplæseren. Præsentation'ens indledende regibemærkninger opregner også syv lydstyrker (fra »meget svag« til "meget kraftig«), »der skal overholdes, også hvis man kun følger udsendelsen gennem én kanal.« - En bemærkning, der lader teksten fremstå som manuskriptet til en radioudsendelse (ligesom den to år tidligere Réseau aérien jo også var). Dette indtryk forstærkes, når man kommer til de efterfølgende 11 dele, som alle indledes med regianvisninger, der opregner DRAMATIS PERSONAE samt det skiftende repertoire af lyde, der indgår i hver enkelt del. I første dels indledende regibemærkninger forklares det, at »Lytteren ... ved at indstille sit apparat (kan) fremhæve den ene eller den anden side mere eller mindre« (p. 17) - en primitiv form for interaktiv radio, baseret på den dengang ret nye stereoteknik, hvor der er en højre og en venstre højttaler, hvis balance indbyrdes kan reguleres. $\mathrm{Og}$ på næste side ekspliciteres forholdet mellem radioversion og læseversion: „Der er altså to sæt variationsmuligheder: i radioen har udsendelsens tilrettelægger valgt et af de ti spor, ved modtageren kan lytteren ændre udsendelsens struktur. // Da man ved læsning er friere stillet end ved aflytning, vil De med bogen i hånden kunne tænke Dem til en hvilken som helst udsendelse« (p. 18). Det er det, der gør romanen til "stereofonisk prosa«, som titelbladet annoncerer. Eftertrykket på læserens eget valg og aktive medvirken i realiseringen af teksten er karakteristisk.

Længere fremme, i regibemærkningerne til del »VII OPVÅGNEN«(p. 138) tilføjes yderligere kommentarer til lydsiden, som synes rettet enten til radioinstruktøren eller kompensatorisk til læseren - f.eks. at når styrketrinnet kommer ned under 'meget svagt', »opstår en stilhed, som interpunkteres af korte eller meget korte meget svage lydindslag.« Det må en læser jo forestille sig. Eller: „Lydene kan variere i styrke og hyppighed, men navnlig varierer de i betydning; betegnelsen, de har fået, ${ }^{10}$ angiver deres form og oprindelse, betydningen får de automatisk i en kontekst, hvor de samme ord forekommer; der er ingen af lydene, som ikke også kan bidrage til at beskrive vandet.«

10. F.eks: pusten, puslende dyr, brusere, torden, latter, åndedrag, smakkende dore, skibssirener, elevatormaskineri, smoeldende flag m.fl., i regilisten p. 137. 
Det omtalte »flydende monument« er selvfølgelig romanen, som således kan skulpteres vekslende af sine læsere, alt efter hvordan de vælger at følge sporene enkeltvis eller samtidigt og i hvilken rækkefølge. Men det er også vandfaldet Niagara, hvis 6.810.000 liter vand i sekundet har givet romanen dens titel, og som i romanen beskrives både som det romantisk-dramatiske naturmonument, det er i den franske forfatter Francois-René de Chateaubriands skildring fra hans Amerikarejse i 1791 (som vi får præsenteret af speakeren og foredraget af oplæseren i lidt opstykket form i Præsentation'ens hoveddel), og som det populærkulturelle, kommercielle turist-monument, det har udviklet sig til som valfartssted for amerikanske nygifte (hvad speakeren ligeledes introducerer i første del og uddyber i anden del).

Hver af de 11 dele, der følger efter den indledende »Præsentation«, begynder med en redegørelse for de ti spor og de mulige ruter gennem dem (F.eks. p. 16: spor ABC springer de to parenteser over, som indgår i hver del og er holdt uden for tidsregningen, spor DEF læser parenteserne med, men sletter højre spor (= de nygifte), spor GHIJ læser det hele - i andre dele er de yderligere differentieret). Dernæst følger en regibemærkning med opregning af afsnittets persongalleri, som altid omfatter: "speaker", "oplæser", et "ældre ægtepar« og et par nygifte »just married« (dvs. par med tidsmæssig forskel). Hertil kommer med vekslende hyppighed: "gartnere«, "negre«; kombinationen "gammel vamp« + "gigolo«; kombinationen »billig forfører» (mand) + »villigt offer« (kvinde); »ung enlig mand«; »ung enlig kvinde«; »enkemand« (som i 4 tilfælde er neger); »enke« (sjældnere, i 2 tilfælde neger) og endelig i sidste afsnit "XII CODA « også en "franskmand, visiting professor, ved universitetet i Buffalo« ved navn Quentin (p.25l) - der kun har én replik, hvori han længes efter sin kone (» $\mathrm{Og}$ jeg er langt fra min søde kone, adskilt fra hende af hele det vældige Atlanterhav...«, p. 254), og måske kan ses som en repræsentant for forfatteren, som i en periode var gæsteprofessor i USA - eller måske snarere som en repræsentant for Chateaubriand, der i årevis var skilt fra sin kone i Frankrig, mens han rejste til Amerika og var flygtning i England fra den franske revolution.

Perspektiveret af disse personer - der nok individualiseres, men også (som regibemærkningerne angiver) står som typerepræsentanter eller stereotyper, endda så vidt at en del af deres replikker gentages helt eller delvis i de sidste dele - skildrer bogen Niagara Falls i nutidig skikkelse, bl.a. i form af opremsninger, lister:

\footnotetext{
"tallerkener med vandialdsmotiv, (...) skjorter med vandfaldsmotiv, (...) askebaegre med vandfaldsmotiv, (...) medaljoner med vandfaldsmotiv af sommerfuglevinger, (...) servietter med vandialdsmotiv, (...) postkort
} 


\section{med vandfaldsmotiv, diapositiver med vandfaldsmotiv, vandfald som mimiklosetter, puder med vandfaldsmo- tiv, vaegmaitter med vandfaldsmotiv, kmapper med vamdialdsmotiv, (...) sengelamper med vandfaldsmotiv, (...) små nogne fajancedamer, hvis bryster kan tages af og bruges til salt og peber, (...) slips med vandfaldsmo- tiv, (...) karafiler med vandfaldsmotiv, (...) hårborster med vandfaldsmotiv $\ll($ p. $20-21)$.}

Speakerens opregning af den moderne turistudgave af vandfaldene (fede typer) brydes på bogsiden af lydeffekterne (i kursiv) og personernes snart naivt betagede, snart kyniske, snart romantiske, snart nostalgiske reaktioner på stedet (almindelige typer) og angivelse af den talende (med kapitæler) i marginen. I opholdene mellem de opregnede mængder af genstande med vandfaldsmotiv citeret ovenfor fører de to nygifte BETTY OG ABEL f.eks. en højstemt romantisk samtale fuld af kærlighedserklæringer: »Jeg.../ ... elsker dig./ Dine øjne. / Dine øjne. / Dine øjnes glans./ Dine øjnes perler. / Dine læber.« Og denne polyfone nutidsskildring kontrasteres til stadighed med Chateaubriands romantiske naturskildring fra 1791 (i kursiv).

Således prismatisk opbrudt skildres vandfaldsområdets bygnings- og anlægshistorie, blomsterparken med dens vekslende flor og farver (regibemærkninger angiver de vekslende stemningslejer, eksempelvis det lyrisk-erotiske, der knytter sig til blomster og farver, jf. f.eks. p. 39: „Forsøg ikke at lade negrene tale med accent. Forsøg ikke at være lyrisk i blomster »lectures«; giv dem blot et diskret erotisk anstrøg«). Farveforskellene mellem blomsterne kontrasteres med farvens betydning blandt mennesker (negrene beretter selv bl.a. om herskabernes nedladende behandling, og datidens amerikanske racefordomme ses i en del af det øvrige persongalleris reaktioner på negrenes tilstedeværelse). Ligeledes berettes der om de forskellige vandfald, øer og tilknyttede turistanlæg og rundvisning; om fyrværkeriet og illuminationen, souvenirboderne, hotellerne og restauranterne; om turistbådene over floden neden for vandfaldene; om de forskellige vandfalds højde, bredde, vandets dybde og forhistorierne om dem, der sejlede ned ad vandfaldet i tønder, gik på line over etc. Alt i alt en ganske grundig rundvisning på stedet - der efterlader læseren med indtrykket af næsten selv at have været der, på turistomvisning incl. brochuredata om forhistorie mv.

Denne rundvisning på stedet bliver samtidig via det vekslende persongalleris replikker og synsvinkler en rundvisning i et spektrum af menneskelige forholdsmåder over for kærligheden, døden, ensomheden, forførelsen, savnet, nostalgien etc. 
»Tilegnet rejsende i Den nye Verden« står der på titelbladet - og bogen kan da også ses som et eksemplarisk portræt af USA: »Den nye Verden« som hjemsted for drømme og utopier, sådan som det amerikanske kontinent fremstod for oplysningstidens og romantikkens rejsende, f.eks. Chateaubriand, og som det stadig lever videre i de amerikanske mytologier om USA som et uskyldens land (over for den bedærvede gamle verden i Europa), Guds eget land eller frihedens rige. Eller nutidens billede af USA som et velstandens og normløshedens konsumparadis. Butors eksemplariske portræt af USA kan både læses i en sociologisk-antropologisk ånd og som (kultur)kritisk.

Som Amerikaportræt kan romanen sammenlignes med Mobile (1962), der bærer undertitlen »Étude pour une représentation des États-Unis«, og indgå i den lange kæde af franske blikke på USA, fra Chateaubriand til Baudrillard.

\section{En postmoderne roman.}

Set fra et nutidigt standpunkt er der mange træk ved Butors roman, der kan karakteriseres som postmoderne:

Den naturtilstand, der kontrasteres med den moderne turistpark omkring vandfaldene, optræder i form af citater fra François-René Chateaubriand (1768-1848) - en af de mest ansete franske romantiske skribenter, både forfatter til historiske værker og lyrik og prosa, kendt for sin stilistiske brillans, sin lyriske tone og den snævre sammenhæng mellem liv og værk.

Chateaubriand besøgte vistnok Niagaravandfaldene på sin Amerikarejse i 1791, sådan som det også oplyses indledningsvis i Butors roman i APRILafsnittet:

\section{SPEAKEREN I året 189I mener man, at grev François- René de Chateaubriand besogite Niagaravandfaldene.}

\section{1898 kom den beromte skildring af dem i hams "His- toriske, politiske og moralske betragtninger over tialligere og moderne revolutioner og deres relationer til Den store franske Revolution« (p. 11),}

hvorefter OPLÆSEREN fortsætter med at læse et uddrag af Chateaubriands meget smukke, både eksakte og eksotiske beskrivelse af vandfaldene i naturtilstanden. 
På Amerikarejsen stilede Chateaubriand netop mod "Den nye verden", idet han her håbede at finde 1) en nord-vest passage 2) den ædle vilde (indianer) og 3) en fremtidig »canadisk roman«. Dvs. »Den nye verden« med civilisation, kunst og styreform udsprunget direkte af naturtilstanden. Forventningerne skuffedes, bl.a i mødet med demoraliserede indianere i reservaterne. Under Amerikaopholdet skrev Chateaubriand et oprindeligt manuskript på ca. 2000 sider, hvorfra han i første omgang publicerede dele, bl.a. i værket Essai sur les révolutions fra 1797 (som der henvises til i Butors optakt) og i romanen Atala fral801, som skildrer et pittoresk indianersamfund og en umulig lidenskab med fatal udgang og på mange måder bliver skoledannende for fransk romanpoetik. Fra denne roman citeres beskrivelsen af vandfaldene til slut i Butors roman, hvis sidste ord lyder:

\section{"Dette er den beskivelse af vandialdene, som Francois-René de Chateaubriand udgav den 2. april IADI i sin roman "Atala, eller kaerligheden mellem to vilde i orkenen« (p. 261).}

Selve Chateaubriands rejsebeskrivelse Voyage en Amérique udkommer først mange år senere i 1827. Og efterfølgende har det været omdiskuteret, hvor mange af de beskrevne steder, Chateaubriand egentlig havde besøgt, og hvor mange beskrivelser, der var fiktive, kun tilsyneladende selvoplevede, eller ligefrem et falsum.

Ved at sammenholde Chateaubriands skildring med beskrivelsen af de moderne Niagara Falls, dementerer Butor indirekte de romantiske forestillinger om "en ny verden« vokset direkte ud af naturtilstanden - samtidig med at det moderne Amerikas masseromantik, forbrugs- og turistglans fremtræder i al sin kunstighed i kontrast til det beskrevne natursceneri. Ud af det chateaubriandske oprindelighedsbillede vokser en noget anderledes modernitet, end Chateaubriand forestillede sig. Butor sætter sig ikke til doms over hverken det romantiske eller det moderne billede af vandfaldenes USA, men lader dem tværtimod stadig vibrere mod hinanden. Faktisk kan man ikke være sikker på, om der er tale om ironi eller kritik i romanens skildring af turistvandfaldene - skønt de lange opremsninger af genstande med vandfaldsbilleder næppe kan undgå at give et grotesk eller ironisk indtryk, ligesom de gentagne replikker synes at pege på en vis stereotypi hos de valfartende romantiske par. Men det kan også læses som popkunstagtige fascinationsbilleder fra massekulturen og indrømmelse af almen meddelagtighed i kulturindustriens klicheer. Måske er det blot to ligeværdige takes af Niagara Falls, to tidsforskudte optagelser eller tekstmodeller, 
monteret i en collageagtig drejning om hinanden - en mobile (ligesom Butors andet forsøg på en skildring af USA).

Man kunne tilmed hævde, at Butors roman på karakteristisk postmoderne vis sætter spørgsmålstegn ved modsætningen mellem det oprindelige og det kunstige. Romanens oprindelsesbillede af Niagara Falls er jo ikke et stykke dokumenteret virkelighed, men en tekst, der ikke blot indgår i en bestemt personlig, (litteratur)historisk og national kontekst med tilhørende indlejrede konventioner og optikker, men som ovenikøbet foreligger i flere versioner - og måske dybest set kan beskrives som et falsum, i den forstand at fremstillingen er opdigtet, en konstruktion på grundlag af andenhånds materiale snarere end det selvoplevede syn, der postuleres retorisk. Det oprindelige fremtræder således i romanen som ligeså kunstigt som nutidens fabrikerede paradis for nygifte.

Som det allerede fremgår, er Butors roman som andre postmodernistiske værker hyperopmærksom på sig selv som tekst, fuld af metatekstuelle og intertekstuelle referencer. Hele Butors romantekst, fraregnet det indledende korte afsnits præsentation og regibemærkninger, er således indlejret i Chateaubriands tekst, som der omhyggeligt henvises til. Den er altså markeret som litteratur skrevet oven på eller inden i anden litteratur. Butor lægger sig inden i Chateaubriands ramme, skriver som Chateaubriand om Amerika, den nye verden, og blander som han reportage og fiktion. Undervejs både citerer og sønderbryder han Chateaubriands værk, så der på en gang bliver tale om en (nostalgisk?) celebrering af den klassiske tekst, der kommer til at udgøre den oprindelsestilstand, den moderne virkelighed/tekst sammenholdes med - og samtidig en dekonstruktion eller grotesk-vrængende-surrealistisk demontering af både den smukke tekst og den naturtilstand, den postulerer.

I første omgang citeres forholdsvis fortløbende, med indlagte regibemærkninger til OPLASEREN, fra Chateaubriand, f.eks.:

højtideligt:

Den del af flodmasserne, som strømmer mod syd, hvalver sig og afrundes til en umådelig stor cylinder $i$ det øjeblik, den slipper randen, derefter breder den sig ud til et snedakke og skinner $i$ alle spektrets farver; den nordlige falder ned $i$ et uhyggeligt mørke som en syndflodssøjle.

langsommere:

Talløse regnbuer hvalver sig og skcerer hinanden over afgrunden, hvis forfardelige brusen kan høres i tres miles' omkreds. 
langsomt og fornemt:

$N a ̊ r$ vandet slår mod den vigende klippe, springer det tilbage $i$ skumhvirvler, som ligner totte røgskyer fra en storbrand, der løfter sig op over skovene.

langsomt, meget højtideligt:

Enorme klippestykker, $i$ spøgelsesagtige former, smykker den storslåede scene; vilde nøddetraer med rødlig skcellet bark vokser forkrøblet hen over disse fossile skeletter (...)

Der er intet levende vasen, (...) bortset fra ørnene, (...)

bortset fra ornene, som svavende over vandfaldet, hvor de har hentet bytte, bliver (...) ført med luftstrømmen og tvunget til at cirkle nedad til kløftens bund.

(...)

En stribet carcajou ${ }^{11}$

(...)

hoenger $i$ sin lange hale

(...)

yderst på en lavtsiddende gren

(...)

og prøver at fange

(...)

rester

(...)

af elsdyrs

(...)

og bjørnes

(...)

druknede kroppe

(...)

11. I den danske oversættelse oplyses det, at »En carcajou er nærmest en jærv. Flere dyr står nævnt i de forskellige ordbøger, men ingen af dem svarer til den beskrivelse, Chateaubriand giver af carcajou'en. Butor mener, at Chateaubriand har brugt navnet som betegnelse for en slags fabel- eller fantasidyr. (O.a.)«, p. 13. 
Efterhånden som citatet skrider frem, skyder SPEAKEREN flere og flere bemærkninger ind om, hvor "anderledes alt ser ud i dag ", hvad allerede Chateaubriand var opmærksom på, ,la han gentog beretmingen om sin rejse i sine "Wrindringer fra hinsides graven" (p. 12, 13). Og i romanens løb udsættes Chateaubriands oprindelsestekst i stigende grad for deformering, fragmentering og deturnering, der forvandler tekstens retoriske kraft til groteske eller surrealistiske udsagn som:

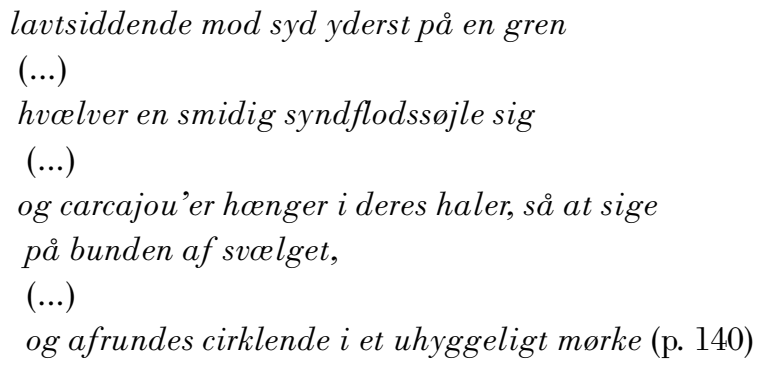

Eller heterogene stumper indfarves af stemningen, som i en passage, hvor det bliver uvejr om natten, og SPEAKEREN taler først om i den sorte nat (...) i den sorte regn og dernæst glider videre til blod (...) blodregn (...) sort blodregn (...) sort gammel blodregn i natten (...) blod fra de myrdede som stonnende gair igen i den sorte mat (p. 124-126). Ind i dette gotiske spor, som også findes i Chateaubriands tekst, skydes så foruden personernes desillusion og utilpashed i natten citatstumper fra Chateaubriand, men brudt op til ukendelighed:

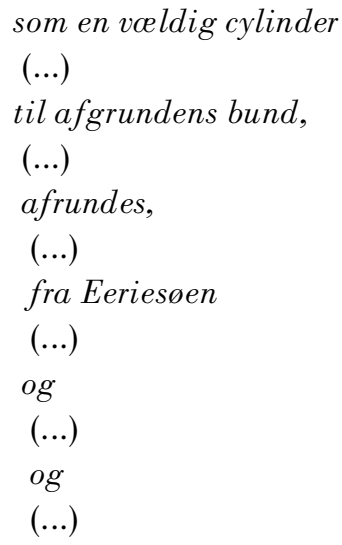


er at

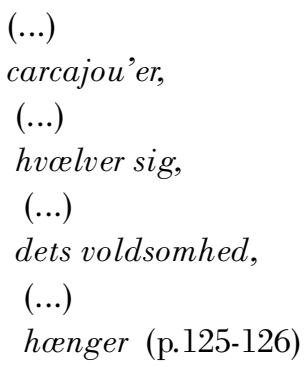

Her hakkes den romantiske tekst op til noget, der nærmest ligner konkret poesi, hvis det læses som et spor for sig, eller rester af en udvisket underliggende tekst, i hvis huller romanens egne tekstspor træder frem. I øvrigt ligner teksten her ligesom flere andre steder i sin typografiske fremtræden snarere poesi, et manuskript til oplæsning af lyddigte eller en drejebog til film eller teateropførelse. Og de forskellige heterogene tekstspor og -fragmenter forbinder sig på tværs med hinanden til sælsomme ordguirlander og stemningsbilleder, hvis man læser dem frit som flersporspoesi i stedet for at følge romanens fremadskridende forløb.

I sig selv kan de mange spor og synsvinkler i bogen læses som et postmoderne udsagn om, at sandheden er relativ, idet enhver ser fra sin subjektive synsvinkel - selv om læseren har mulighed for at danne sig et større overblik over summen af synsvinkler.

Også den delvis cirkulære opbygning af Butors tekst, hvor de sidste dialoger delvist gentager de første, kunne læses som et postmoderne udsagn om, at befinde sig i en efter-tid, hvor alting allerede har fundet sted, så at der ikke er mere nyt i verden - og derfor heller ikke mulighed eller brug for at opfinde noget nyt i kunsten. Snarere må man genbruge det klassiske stof (her repræsenteret af Chateaubriand), evt. i en bevidst fejllæsning, genlæsning eller anden form for bearbejdning, sådan som bl.a. feministiske og andre politiske postmoderne læsere har plæderet for.

Også romanens sammenføjning af det høje og det lave - Chateaubriand som repræsentant for finlitteraturen og den klassiske arv over for Niagara som monument over massekulturen og den kommercielle amerikanske kulturindustri - kunne ses som kendetegnende for postmodernismens overvindelse af kløften mellem høj og lav kultur, sådan som bl.a. Andreas Huyssen har defineret den. ${ }^{12}$

Overfor dette nu velkendte postmoderne synspunkt, kan det være nyttigt at gå tilbage og korrigere i forhold til tresseravantgardens egen optik.

12. After the Great Divide. Modernism, Mass Culture and Postmodernism, London 1986. 
Lad os med andre ord gå tilbage til Butors essay »Le roman comme recherche« og andre romanpoetologiske essays.

\section{Tresserperspektiv}

I »Le roman comme recherche« fra $1955^{13}$ definerer Butor romanen som en bestemt form for fortælling, og fortællingen som en grundlæggende modus i vores erkendelse af virkeligheden. Fortælling kan tage mange former, og Butor skelner nu mellem de sagprosa-fortællinger, der kan verificeres (sandfalsk), og fiktion, der præsenterer os for begivenheder og fænomener der ligner dagligdagens, men som ikke kan verificeres. Det er ret velkendt stof.

Det interessante er nu, hvad Butor slutter herudfra: nemlig, at eftersom romanen ikke støtter sig på eksternt bevismateriale, så er romanen = fænomenologiens område par excellence. Den er det sted, hvor det er muligt at undersøge, hvordan virkeligheden fremtræder for os eller kan fremtræde for os. »Romanen er fortællingens laboratorium«, og derfor har arbejdet med romanens form en stor betydning, hinsides det blot æstetiske (E, p. 9).

Hertil føjer Butor et litteratur- eller diskurshistorisk perspektiv: De verificerbare fortællinger stivner i historiens løb til bestemte, tilvante former, der kommer til at dække over »den reelle erfaring« eller forveksles med denne, så der opstår en "mystification généralisée« $(E$, p. 9). Arbejdet med nye fortællemåder kan nu vise, hvad der er kontingent, dvs. konventionsbestemt, i de former, vi har vænnet os til, og medvirke til at afdække virkelighedsområder, som er blevet skjult eller fortiet bag konventionen: "nye former vil afsløre nye tings realitet «. Og omvendt svarer der til nye, anderledes former for virkelighed også nye fortælleformer, mens de traditionelle fortælleteknikker er ude af stand til at integrere de nye forhold, som Butor, med et karakteristisk tresserperspektiv, ser dukke op med særlig påtrængende voldsomhed netop i sin epoke ( $E$, p. 10$)$ - hvad der i bakspejlet heller ikke er forkert: alle de teknologiske, sociologiske, politiske, globale forudsætninger for det, man kan kalde den postmoderne tilstand, vi lever i idag, kommer på plads i tresserne.

Butor konkluderer, at romanforfatterens formeksperimenter har en trefoldig rolle i forhold til vores virkelighedsopfattelse: „de dénonciation, d'exploration et d'adaption", forkastelse, udforskning og tilpasning ( $E$, p. 10). Formeksperimenterne i romanen er altså langtfra i modsætning til realismen, men tværtimod en forudsætning sine qua non for en mere fremskre-

13. Jeg henviser til Michel Butor: Essais sur le roman, Paris 1997 (herefterforkortet E), et samlebind med de vigtigste Butors kritiske artikler udvalgt fra fembindsværket Répertoires. 
den form for realisme ( $E$, p. 11$)$. Og denne nyopdagelse af virkeligheden gælder ikke kun for romanens tilblivelse/produktion, men også for læsningen/læseren.

Interessen for romanen som eksperimentelt område i 1950’erne og 1960 'erne er således langtfra at forstå som "rent æstetiske«, "verdensfjerne« avantgardistiske »formeksperimenter« eller postmodernistiske tekstualiteter uden reference til sociale, historiske og politiske forhold. Der sker her ikke blot en forskydning fra »det skønnes« æstetik og de hævdvundne litterære konventioner, men formsproget forstås som noget, der har en ny social betydning.

Butor henviser både i "Le roman comme recherche» og andetsteds eksplicit til fænomenologien, og han opfatter tydeligvis romanen som en sproghandling, der indgår i en interaktion med læseren: Et jeg forudsætter altid et du, og på samme måde ses tekster ikke som autonome værker, men som replikker i en social dialog, baseret på et fælles kulturelt repertoire. I sin artikel om romanpersoner og brugen af personlige pronominer, "L'usage des pronoms personnels dans le roman « fra 1964, ${ }^{14}$ konkluderer Butor således, at romanens personer må opfattes mindre som bundet til et fysisk individ (som f.eks. forfatteren i det tilfælde, hvor der står »jeg« i teksten) og mere som »en funktion, der opstår i et mentalt og socialt miljø, i et dialogisk rum« $(E, \mathrm{p}$. 88).

Butor definerer de samtale- og interaktionsmuligheder, de personlige pronominer muliggør, som et dialogisk grundsystem i sproget:

"Alt sprog er først og fremmest dialog, hvad der indebærer at det ikke kan være et isoleret individs udtryk. Hvert ord vi hører forudsætter en første og en anden person. Jeg forstår hvad folk siger til hinanden før jeg ved, hvem de er, og de to poler som står over for hinanden defineres for mig af deres indbyrdes korrelation. Det samfund jeg tilhører er en samling dialoger, dvs. at enhver kan komme til at sige noget (ikke hvadsomhelst) til enhver anden, det er en helhed som organiserer sig i underafdelinger: jeg taler ikke på samme måde til alle dens medlemmer...." osv. ${ }^{15}$

Udfra denne grundlæggende definition bestemmer Butor også romanen som dialogisk - længe før Bakhtin er kendt i Vesteuropa - skønt de dialogiske former skifter i løbet af den historiske udvikling fra epos over pikaresk til den borgerlige roman, således at den lineære romankonstruktion gradvis

14. Ligeledes optrykt i $E$.

15. »Individu et groupe dans le roman«, in E, p. 104. 
viger for en polyfonisk, som Butor skitserer det i artiklen om »Individ og gruppe i romanen«. Den polyfone skrivemåde er allerede til stede i 1700-tallets flerstemmige brevroman og udbygges i de store attenhundredetalsromaner til en polyfoni af sociale miljøer. ${ }^{16}$ Romanen er dialogisk i sin fremstilling af relationer, men idet læserens synsvinkel og opfattelse indbygges i de beskrevne relationer, frembringer romanen også skiftende forholdsmåder fra læserens side til tekstens univers:

"Romanfiguren kan aldrig helt bestemmes, han forbliver åben for at jeg kan sætte mig i hans sted eller i det mindste placere mig i forhold til ham. Men hvis man kan slå sig ned på forskellige punkter i disse figurer, sådan som en polyfonisk skrivemåde jo forudsætter, følger det så ikke deraf at jeg som læser må kunne bevæge mig ad flere veje?«(E, p. 107).

Denne bestræbelse i retning af en mere udbygget polyfoni, hvor flere bevægelser, positioner og begivenheder krydses og åbner sig i alle retninger, fortsætter den moderne roman - og ikke mindst Butors egne romaner. Som den svenske litteraturforsker Beata Agrell $^{17}$ har gjort opmærksom på, tjener romanfigurerne i den sammenhæng som stedfortrædende positioner for læseren, der selv er lige så åbne og bevægelige som hele den sammenhæng, de indgår i. Butors romaner bygges ofte op omking rejsen som foretrukket topos og metafor for den tilstræbte bevægelighed. I læseakten fungerer personerne som færdselsmidler for læseren, der muliggør forskellige rejser gennem romanen - sådan som det ekspliciteres i regibemærkningerne til Seks millioner otte hundrede ti tusind liter vand $i$ sekundet og typografisk koreograferes i romansidernes forskellige spalter og typer. Men læseren tvinges også til jævnligt at skifte position. Romanens opbygning skaber en stadig forskydning af positioner og perspektiver, en stadig vekslen mellem identifikation og distance. Butor konstruerer flere af sine romaner som mobiler for at fremkalde netop denne bevægelighed og deraf følgende refleksionsproces.

Med Agrells formulering ligger romanens egenart for Butor og andre samtidige romanforfattere ikke i fortællingen, men i det fortællende eller episk fremvisende, i selve romanens karakter af (til)talehandling. Romanens

16. E, p. 106 .

17. Beata Agrell redegør i sin disputats Romanen som forskningsrejse, forskningsrejsen som roman, Göteborg 1993, for Butors romaner og litteraturkritik som en af forudsætningerne for den svenske 60ertalsroman og dens "litterära återbruk och konventionskritik«, som det hedder i værkets undertitel. Butor behandles pp. 180-85. Agrells vægt på fænomenologi og social interaktion som baggrund for tressernes eksperimentalprosa ligger på linie med min egen opfattelse af de eksperimenterende tressere $\mathrm{og}$ hendes ofte præcise formuleringer er opsuget i flere af mine pointer i slutningen af nærværende artikel. 
grundlæggende dialogiske karakter kræver altså ikke, at fortællingen mimetisk efterligner dialoger, antager dialogform, men derimod at præsentationen af det ene og det andet forholder sig dialogisk til en læserposition. Og det er først i forhold til denne læserposition, fortællingen træder frem.

På den måder er romanen det, den viser: på en gang tekst, ytring og talesituation. På en gang diskursiv ordning, æstetisk tiltale og social situation. $\mathrm{Og}$ romanens yderste hensigt er at tjene som handlingsinstrument i denne situation: at »forsyne hver af os med de værktøjer, vi har brug for at forstå bevægelserne i de grupper, vi indgår i«, sådan som Butor konkluderer i sin artikel om «individet og gruppen i romanen« $(E$, p. 108).

Opgaven er altså social og politisk, men værktøjet er fænomenologisk og knyttet til omformningen af sprogligt-litterære former. Denne transformation af romanformen vil »meget langsomt men uundgåeligt«, mener Butor, føre frem mod »en ny form for poesi, der på én gang er episk og didaktisk, som led i en transformation af selve opfattelsen af litteraturen der ikke længere vil fremtræde som simpel afslapning eller luksus, men i sin essentielle rolle i den sociale sammenhæng« $(E$, p. 14$)$. I det perspektiv er Butors romaner at forstå som sproglig aktivisme.

Denne utopiske vision af, hvordan litteraturen rykker ind på sit retmæssige centrale gebet i samfundsbygningen, er næppe gået i opfyldelse, selv om det interaktive, dialogiske og synsrelativistiske jo unægtelig er slået igennem (om ikke andet så som slogan) i de moderne demokratier og massemedier. Ethvert barn kan idag udføre de operationer, Butor tilskriver læseren af polyfone romaner, i hvert fald i forhold til de visuelle medier. $\mathrm{Og}$ det er måske ikke uden sammenhæng med den grundforskning, som Butor og andre udførte i deres prosaeksperimenter i 1950’erne og 1960'erne. 